This manuscript is contextually identical with the following published paper:

Táborská, M., Procházková, J., Lengyel, A., Vrška, T., Hort, L., Ódor, P. 2017. Wood-inhabiting bryophyte communities are influenced by different management intensities in the past. Biodiversity and Conservation 26: 2893-2909. IF(2016): 2.265. doi: 10.1007/s10531-017-1395-8. The original article is published at https://link.springer.com/article/10.1007\%2Fs10531-017-1395-8

\title{
Wood-inhabiting bryophyte communities are influenced by different management intensities in the past
}

Authors: M. Táborská ${ }^{1,2}$, J. Procházková2 ${ }^{2}$ A. Lengyel ${ }^{3}$, T. Vrška ${ }^{1}$, L. Hort ${ }^{1}$, P. Ódor ${ }^{4}$

${ }^{1}$ Department of Forest Ecology, Silva Tarouca Research Institute, Lidická 25/27, CZ-602 00 Brno, Czech Republic; e-mail: taborska.mar@gmail.com, tel. +420 739617682

${ }^{2}$ Department of Botany and Zoology, Faculty of Science, Masaryk University, Kotlářská 2, CZ-611 37 Brno, Czech Republic

${ }^{3}$ MTA Centre for Ecological Research, Large-scale Vegetation Ecology Research Group, H-8237 Tihany, Klebelsberg K. u. 3., Hungary

${ }^{4}$ MTA Centre for Ecological Research, Forest Ecological Research Group, H-8237 Tihany, Klebelsberg K. u. 3., Hungary

\section{Abstract:}

Many studies have underlined the fact that once forest continuity is broken, communities of woodinhabiting organisms may never be restored to their original status. However, only a few studies have actually presented results from sites that have current old-growth structure, and where the history of human interventions is known. In this study we compared the species richness, nestedness, beta diversity, and composition of bryophytes from living trunks and dead logs of beech (Fagus sylvatica) in seven forest stands in the Czech Republic with old-growth structure and various histories of past human impact. Our analysis showed that these communities are nested and that their beta diversity is lower than random. There was a significant proportion of shared species, and rare species were present only in the most heterogeneous and the least man affected habitats. We found that bryophyte communities of forests with more intensive past management were significantly impoverished in terms of both species richness and composition. Beta diversity was not related to management history and reflected current habitat heterogeneity. The effect of decay stage on species richness and beta diversity was stronger than the site effect. Our results demonstrate that the protection of current natural beech-dominated forests and improvements to their connectivity in fragmented landscapes are crucial for the survival and restoration of the diversity of wood-inhabiting bryophytes.

Key words: beech; beta diversity; bryophytes; Central Europe; dead wood; management history

\section{Acknowledgements:}


The authors are grateful to $\mathrm{D}$. Adam for the preparation of data from stem position maps and $\mathrm{S}$. Kubešová for help with identification of problematic species of bryophytes. David Hardekopf kindly improved the English of the manuscript. The study was supported by the project Deadwood decomposition dynamics in natural temperate forests (GAP504/13-27454S), data were collected in the framework of the project Monitoring of natural forests of the Czech Republic (EHP-CZ02-OV-1-0212014). Hungarian authors were supported by the National Research, Development and Innovation Office (GINOP 2.3.3-15-2016-00019).

\section{Introduction:}

Beech-dominated forests are one of the major types of natural vegetation in the temperate zone of Europe (Bohn et al. 2003; Box and Fujiwara 2005). Due to its broad ecological amplitude and high competitiveness, beech (Fagus sy/vatica) dominates forests at different environmental ranges (Leuschner et al. 2006), and can occur in combination with a broad spectrum of other tree species, like silver fir (Abies alba) and spruce (Picea abies) in harsher climatic conditions and maples (Acer platanoides, A. pseudoplatanus), hornbeam (Carpinus betulus), ash (Fraxinus excelsior) and oaks (Quercus robur, Q. petraea) in milder climate zones (Peters 1997; Standovár and Kenderes 2003).

Temperate broadleaved forests have generally been heavily affected by human activities. Even before the introduction of forestry in the $18^{\text {th }}$ and $19^{\text {th }}$ centuries, beech forests had been pastured for centuries and selectively cut for timber (Hahn and Fanta 2001). Large areas had been also coppiced for firewood and other purposes, although beech has a relatively low ability to produce vegetative shoots (Peters 1997). With increasing demand for timber in the $19^{\text {th }}$ century, many of these forests were cleared and replaced by coniferous plantations. Most of the recent beech forest stands are managed by rotation forestry systems, mainly a shelterwood forestry system using 100-120 years as the rotation period (Hahn and Fanta 2001). This type of management results in even aged monodominant stands with low structural heterogeneity (Brunet et al. 2010). Modern forest management has a serious negative impact on the overall diversity of forest species and thus ecological stability (Larsen 1995; Gamborg and Larsen 2003; Brunet et al. 2010). Tree species and age unification along with a significant reduction of senescent trees and coarse woody debris in forests negatively influence species across different groups (Harmon et al. 1986; Samuelsson et al. 1994; Jonsson et al. 2005; Friedel et al. 2006; Fritz et al. 2008a; Halme et al. 2013). One of the species groups most threatened by the exploitation of temperate forests are epixylic bryophytes (inhabiting decaying wood). Many studies have shown that the diversity of epixylic bryophytes is directly linked to the coarse woody debris of different tree species, volumes and decay stages (e.g. Rambo and Muir 1998; Ódor and Standovár 2001; Ódor and van Hees 2004; Táborská et al. 2015), which is rather scarce in managed forests. Epiphytic bryophytes (inhabiting the trunks of living trees) are also very sensitive to forest management. Many species are associated with large, veteran trees because they can provide the necessary microhabitats and allow a sufficient time for the colonization of dispersal-limited species (Fritz et al. 2008b; Madžule et al. 2011; Király et al. 2013). These assemblages are also very sensitive to forest continuity and fragmentation (Löbel et al. 2006; Ódor et al. 2006; Snäll et al. 2004).

With the greater recent emphasis on nature conservation in Europe, remnants of natural and oldgrowth forests are often protected by law, and there has been an effort to restore beech forest sites that have been disturbed in the past (e. g. Zerbe et al. 2002; Bauhus et al. 2009; Felton et al. 2010). There have been many studies concluding that once the continuity of a forest is disturbed (including from the point-of-view of certain substrates such as large senescent trees or decaying logs), the full restoration of specialist communities may be long delayed and in some cases is not even possible (Andersson and Hytteborn 1991; Similä et al. 2003; Ódor et al. 2006; Moning and Müller 2009; Heilmann-Clausen et al. 2014). But few of these studies have actually presented results from sites 
which have current old-growth structure and where the history of disturbances is known (Fritz et al. 2008a).

One way to describe and compare community structures on a gradient of management history is the analysis of beta diversity (Anderson et al. 2011). According to Podani and Schmera (2011) and Carvalho et al. (2013), beta diversity patterns consist of two distinct processes: species replacement and species loss (or gain), the latter being closely related to nestedness. Nestedness refers to the extent that species-poor assemblages are a subset of species-rich ones (Atmar and Patterson 1993) and therefore it can give us valuable information about the distribution of certain species. In the case of fragmented habitats it is usually related to patch size and the level of isolation (Berglund and Jonsson 2003; Hokkanen et al. 2009; Fahrig 2013).

In this paper, we explored the patterns of epiphytic and epixylic bryophyte assemblages in beech dominated forest reserves of different management history in the Czech Republic. Our aim was to contribute to the general knowledge of wood inhabiting (epiphytic and epixylic) bryophyte communities in long-term unmanaged beech-dominated forests. To accomplish this we examined the bryophyte assemblages of beech trunks and logs (for simplicity hereinafter referred to as logs) of large volumes, focusing on the effect of forest history (between sites) and decay stages (within sites) on the community structure (species richness, beta diversity, nestedness, species composition). Our main questions were:

(i) To what extent do management history and decay stage determine the site and log-level species richness of wood inhabiting bryophytes and the species composition of the communities?

(ii) Are site and log-level beta diversity and nestedness values of the community different from random (neutral) references?

(iii) Are beta diversity values different between and within sites, and between decay stages within sites?

(iv) How is beta diversity related to the management history and species richness of sites?

\section{Material and Methods:}

Study sites and sampling

This study comprised 7 old-growth mixed forest sites with different management histories in the Czech Republic. All of them are currently protected as nature reserves and excluded from logging and other management activities. All sites have old-growth structure with a long-term absence of human influence, characterized by the presence of old veteran trees, regeneration in naturally created gaps, a fine scale mosaic of forest developmental stages and a high amount of coarse woody debris (CWD) (Král et al. 2014a). None of these sites has ever been clear-cut, but different human activities in different combinations were performed at every site except one virgin forest site. Based on historical data we divided them into three groups according to the intensity of past management. The general features of the sites along with their environmental characteristics, management history and derived classification are shown in Table 1. Detailed information about the proportion of living trees and dead wood of important tree species in the total volume for each locality are presented in Table 2. Most of these localities are naturally dominated by beech, with the exception of Boubín, where spruce has a similar dominance as beech (Table 2). 
For the preselection of appropriate logs we used census datasets from all investigated sites. All 2 standing and downed trees of $\mathrm{DBH} \geq 10 \mathrm{~cm}$ at these seven sites had previously been mapped and the 3 DBH recorded. In the 1970`s, 1990`s and 2000's stem-position maps were based on tripod-based 4 theodolite positioning (with sub-meter absolute positional accuracy anticipated). In the 2000 's we also 5 used Field-Map technology (http://www.fieldmap.cz). Tree heights were measured on a sample of ca. $610 \%$ of trees and fitted using Näslund's height curve (Näslund, 1936). Deadwood measurements (incl. 7 lying stem lengths, decay stage determination) were carried out according to the "Deadwood Protocol“ 8 (Král et al. 2014b - supplementary material). 
Tab. 1 Table of seven studied old-growth beech-dominated stands in the Czech Republic with structural and climatic variables and their affiliation to defined management history groups.

\begin{tabular}{|c|c|c|c|c|c|c|c|}
\hline abbreviation & BO & KO & $\mathrm{MI}$ & $\mathrm{PO}$ & SA & ZF & $\mathrm{ZH}$ \\
\hline Reserve & Boubínský prales & Kohoutov & Mionší & Polom & Salajka & Žofínský prales & Žákova hora \\
\hline GPS ("mid-point" of studied area) & $\begin{array}{l}48^{\circ} 58^{\prime} 43^{\prime \prime} \mathrm{N} \\
13^{\circ} 48^{\prime} 43^{\prime \prime} \mathrm{E}\end{array}$ & $49^{\circ} 55^{\prime} 26^{\prime \prime} \mathrm{N}, 13^{\circ} 46^{\prime} 18^{\prime \prime} \mathrm{E}$ & $\begin{array}{l}49^{\circ} 32^{\prime} 11^{\prime \prime} \mathrm{N} \\
18^{\circ} 39^{\prime} 30^{\prime \prime} \mathrm{E}\end{array}$ & $\begin{array}{l}49^{\circ} 47^{\prime} 32^{\prime \prime} \mathrm{N} \\
15^{\circ} 40^{\prime} 20^{\prime \prime} \mathrm{E}\end{array}$ & $\begin{array}{l}49^{\circ} 24^{\prime} 07^{\prime \prime} \mathrm{N} \\
18^{\circ} 25^{\prime} 17^{\prime \prime} \mathrm{E}\end{array}$ & $\begin{array}{l}48^{\circ} 39^{\prime} 58^{\prime \prime} \mathrm{N} \\
14^{\circ} 42^{\prime} 28^{\prime \prime} \mathrm{E}\end{array}$ & $\begin{array}{l}49^{\circ} 39^{\prime} 20^{\prime \prime} \mathrm{N} \\
15^{\circ} 59^{\prime} 39^{\prime \prime} \mathrm{E}\end{array}$ \\
\hline Elevation $(\mathrm{m})$ & $925-1105$ & $417-568$ & $778-890$ & $545-625$ & $715-820$ & $730-837$ & $725-800$ \\
\hline Total size (ha) & 666.4 & 30.1 & 170 & 18 & 21.9 & 101.7 & 38.1 \\
\hline Studied area (ha) & $46.6^{f}$ & 25.3 & 9.4 & 19.3 & 19 & 74.2 & 17.5 \\
\hline Spontaneous development since & ever & 1933 & 1935 & 1925 & 1930 & 1838 & 1929 \\
\hline \multicolumn{8}{|l|}{ Historical management: } \\
\hline deadwood haulage till & never & 1933 & 1935 & 1936 & 1930 & 1888 & 1929 \\
\hline $\begin{array}{l}\text { deadwood haulage full }(f) / \text { partly, } \\
\text { randomized }(p)\end{array}$ & --- & $f$ & $p$ & $f$ & $\mathrm{p}$ & $\mathrm{p}$ & $\mathrm{p}$ \\
\hline selective felling in the past (yes/no) & $\mathrm{n}$ & $\mathrm{n}$ & y & y & y & y & y \\
\hline group felling in the past (yes/no) & $\mathrm{n}$ & y & $\mathrm{n}$ & y & $\mathrm{n}$ & $\mathrm{n}$ & $\mathrm{n}$ \\
\hline $\begin{array}{l}\text { planting or reforestation in the past } \\
\text { (part of the reserve) (yes/no) }\end{array}$ & $\mathrm{n}$ & $\mathrm{n}$ & $\mathrm{n}$ & y & $\mathrm{n}$ & $\mathrm{n}$ & y \\
\hline charcoal burning in the past (yes/no) & $\mathrm{n}$ & y & $\mathrm{n}$ & $\mathrm{n}$ & $\mathrm{n}$ & $\mathrm{n}$ & y \\
\hline Level of human influence in the past ${ }^{a}$ & A & C & B & C & B & B & C \\
\hline $\begin{array}{l}\text { Other common tree species besides } \\
\text { beech }\end{array}$ & Picea abies & $\begin{array}{l}\text { Acer platanoides, } \\
\text { Quercus petraea, Acer } \\
\text { pseudoplatanus, } \\
\text { Carpinus betulus, Tilia } \\
\text { sp., Picea abies }\end{array}$ & Abies alba & Picea abies & Abies alba & $\begin{array}{l}\text { Abies alba, Picea } \\
\text { abies }\end{array}$ & Picea abies \\
\hline Living/dead wood ratio & $65 / 35$ & $85 / 15$ & $69 / 31$ & $83 / 17$ & $68 / 32$ & $60 / 40$ & $81 / 19$ \\
\hline DBH of dead wood ${ }^{b}$ & $80(48,132)$ & $94(72,125)$ & $81(60,105)$ & $108(76,140)$ & $81(55,120)$ & $101(74,129)$ & $91(65,115)$ \\
\hline Bedrock & shist & rhyolite & flysh & $\begin{array}{l}\text { migmatite, } \\
\text { amphibolite }\end{array}$ & flysh & granite & $\begin{array}{l}\text { migmatite, } \\
\text { orthogneiss }\end{array}$ \\
\hline $\mathrm{T}_{\text {ave }}\left({ }^{\circ} \mathrm{C}\right)^{\mathrm{C}}$ & 4.9 & 7.8 & 5.2 & 7.4 & 6.2 & 4.3 & 6.1 \\
\hline Precipitation $(\mathrm{mm})^{\mathrm{d}}$ & 1067 & 597 & 1207 & 774 & 1142 & 704 & 781 \\
\hline References $^{e}$ & Vrška et al. 2012 & Průša 1985 & Vrška et al. 2000 & Vrška et al. 2002 & Vrška 1998 & Pícha 2010, 2012 & Vrška et al. 2002 \\
\hline
\end{tabular}


Three levels: $A=$ no human impact, $B=$ only selective felling, $C=$ combination of more activities.

$2 \quad{ }^{b}$ Mean diameter at breast height (DBH) based on the investigated dead trees, minimum and maximum are in brackets.

3 'Mean annual temperature (source: Czech Hydrometerological Institute, data interpolation from 1981-2011).

${ }^{\mathrm{d} A n n u a l}$ precipitation (source: Czech Hydrometerological Institute, data interpolation from 1981-2011).

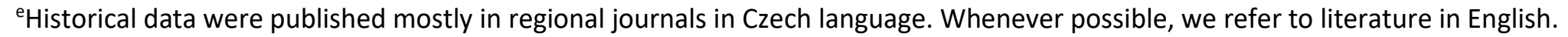

${ }^{\mathrm{f} C}$ Core part which has never been managed by man 46.6 ha.

Tab. 2 Proportions of living trees and deadwood (DBH $>10 \mathrm{~cm})$ in the total volume for individual tree species calculated according to tree counts, basal area and volume for seven studied old-growth beech-dominated stands in the Czech Republic

\begin{tabular}{|c|c|c|c|c|c|c|c|}
\hline site & $\mathrm{BO}$ & KO* & $\mathrm{MI}$ & $\mathrm{PO}$ & SA & $\mathrm{ZF}$ & $\mathrm{ZH}$ \\
\hline \multicolumn{8}{|l|}{$\begin{array}{l}\text { proportion of } \\
\text { deadwood (\% of } \\
\text { volume in total) } \\
\end{array}$} \\
\hline Fagus sylvatica & 16.4 & 88.4 & 32.8 & 40.4 & 15.8 & 25.5 & 54.5 \\
\hline Abies alba & 20.0 & 4.4 & 62.2 & 24.8 & 79.2 & 16.4 & 3.2 \\
\hline Picea abies & 63.5 & 0.0 & 2.7 & 31.1 & 4.9 & 57.7 & 39.8 \\
\hline other & 0.1 & 7.2 & 2.3 & 3.7 & 0.1 & 0.4 & 2.5 \\
\hline total & 100.0 & 100.0 & 100.0 & 100.0 & 100.0 & 100.0 & 100.0 \\
\hline \multicolumn{8}{|c|}{$\begin{array}{l}\text { proportion of living } \\
\text { trees (\% of volume } \\
\text { in total) }\end{array}$} \\
\hline Fagus sylvatica & 45.7 & 80.8 & 78.9 & 17.0 & 68.5 & 62.0 & 73.9 \\
\hline Abies alba & 4.3 & 0.1 & 5.0 & 0.6 & 21.7 & 3.4 & 0.0 \\
\hline Picea abies & 49.8 & 0.7 & 0.2 & 70.7 & 8.9 & 33.4 & 13.5 \\
\hline other & 0.2 & 18.5 & 15.9 & 11.7 & 0.9 & 1.2 & 12.6 \\
\hline total & 100.0 & 100.0 & 100.0 & 100.0 & 100.0 & 100.0 & 100.0 \\
\hline
\end{tabular}


Here we focused on those beech trees with maximum DBH, and selected 35 such logs at each locality. For the purpose of this study we distinguished three decay stages: DS 0 - trunks of standing living trees, 10 per each locality; DS 1 - dead logs in early decay stages characterized by hard wood and high bark cover (corresponding to decay stage 1 and 2 sensu Heilmann-Clausen 2001), 10 per each locality; DS 2 - dead logs in intermediate and late decay stages characterized by soft wood, without bark (corresponding to decay stage 3, 4 and 5 sensu Heilmann-Clausen 2001), 15 per each locality (except for the locality Salajka, where DS 2 was represented by only 12 logs).

In 2015, the presence of bryophytes was surveyed on the whole log surface from the ground to 2 meters high in the case of living trees and on the whole surface of dead logs above ground, excluding branches. If the logs included an uprooted part it was not included in the survey. Species were identified in the field or collected for microscopic identification. Voucher specimens are deposited in herbarium of the first and second authors. The species Hypnum andoi and $H$. cupressiforme were not distinguished and are here referred to together as $H$. cupressiforme. Nomenclature followed Kučera et al. (2012).

\section{Data analysis}

The effect of site and decay stages on log-level species richness was tested by ANOVA with nested error structure (logs of different decay stages were nested within sites, Crawley 2007). The levels of the factors were compared by Tukey multiple comparisons (Zar 1999).

Community diversity structure was explored by the SDR simplex approach proposed by Podani and Schmera (2011). This involves partitioning the relationship between a pair of sample units into three additive components summing up to 1 : similarity (S) as measured by the Jaccard index, species replacement $(R)$ and richness difference $(D)$. Beta diversity (also called turnover, $T$ ) between pairs was expressed as $D+R$, and nestedness (Nest) as $S+D$. These functions were calculated between site pairs (using cumulative species lists of the sites) and log pairs. The R script of the studied functions is given in Appendix 1. The mean of the functions were calculated as descriptive statistics, and the position of the pairs were plotted in ternary plots. These measures are dependent on the proportion of the presence records in the matrix (also called matrix fill) as well as on the total number of species in the matrix. The difference of the statistics from randomness was tested by a Monte-Carlo simulation using 999 restricted permutations of the original matrix keeping the size and the presence fill of the matrix as well as the sampling unit species richness fixed. For more details on the method see Podani and Schmera (2011) and Halme et al. (2013).

The effects of sites and decay stages on the beta diversity of log pairs were then studied in more detail. Within- and between-site beta diversity were compared by a Monte-Carlo simulation (using 999 permutations of the original beta diversity values), and beta diversity between and within decay stages (analyzing only within site pairs) were also studied in a similar way. The effect of sites on within-site beta diversity values and the effect of decay stages on within-site, within-decay stage beta diversity values were tested by $\mathrm{F}$ statistics via a Monte-Carlo simulation and Tukey multiple comparisons. In each analysis, site was used as an explanatory factor, but sites of the same management histories were visualized by colors in the boxplots.

The effect of sites and decay stages on species composition was studied by Redundancy Analysis as a direct ordination method (Borcard et al. 2011). The effects of these factors on species composition were also tested by permutational multivariate analysis of variance (Anderson 2001) using the $R$ function "adonis". 
All analyses were carried out in the R 3.3.2 environment (RCore Team 2013), with the "vegan" package used for multivariate analyses (Oksanen et al. 2013), and the "multcomp" package for multiple comparisons (Hothorn et al. 2008).

\section{Results}

\section{Species richness}

We sampled 243 beech logs and found a total 98 bryophyte species (20 of them were liverworts and 78 mosses). Boubín was the richest site (71), Žofín and the reserves with selective felling in the past had intermediate site level richness (60 in average), while reserves with higher levels of past human activities had the lowest values (50 in average; Fig. 1a). Log-level species richness had similar patterns, and the effect of site was significant (nested ANOVA, $F=5.68, p=0.005$ ): based on multiple comparisons the sites more influenced by human activities (KO and $\mathrm{PO}$ ) significantly differed from those less influenced (Fig. 1b). Log-level species richness significantly differed among decay stages (nested ANOVA, $F=13.63, p<0.001$ ), with living trunks having the highest species richness, the early decay stage having intermediate values, and the late decay stage the lowest (Fig. 2).

\section{Beta diversity and nestedness}

On the site level, the mean values of similarity and richness differences were higher, while species replacement was lower than the randomized values, which indicated higher nestedness and lower beta diversity than predicted by the null model (Fig. 3, Tab. 3). The data points in the ternary plot are closer to the S-vertex and side representing richness agreement, and all points are in the lower part of the triangle. This means that on the site level, the effect of similarity is higher than species replacement in bryophyte communities, which generally indicates low beta diversity. There is a short gradient of nestedness along the bottom side of the ternary plot. The high level of nestedness is also demonstrated by the species list (Appendix 2).

On the log level we found the same patterns as on the site level (Tab. 3). In the case of log-level data, matrix fill is much lower than for sites. This results in a high percentage of species replacement and therefore the beta diversity is increased artificially (Podani and Schmera 2011). The resulting beta diversity index is quite high (0.771), but still lower than in a random community of similar matrix fill. On the other hand, nestedness is higher.

Log-level beta diversity was higher between sites than within sites (Fig. 4a, Monte-Carlo simulation $p<0.001)$. In addition, within-site values of beta diversity were higher between decay stages than within decay stages (Fig 4b, Monte-Carlo simulation $p<0.001$ ). Within-site beta diversity was independent of the species richness of the sites $(F=0.4, p=0.56$, Fig. 5$)$. The effect of site on beta diversity was significant (Fig. $6, F=51.7, p<0.001$ ), but this was not related to forest history. Decay stage also had a significant effect on beta diversity, being higher in the case of decaying logs (DS 1 and 2) than for living trunks (DS 0, Fig. 7, $F=24.23, p<0.001$ ).

\section{Species composition}

In the RDA (Fig. 8), constrained axes determined by tree decay stages and seven sites explained $28.3 \%$ of total variability $(F=37.7, P=0.001)$. The first constrained axis $(11.6 \%)$ was related to the gradient of decay stages, and the second constrained axis (5.6\%) reflected different sites. Samples from localities with past human interventions were mostly associated with positive RDA2 values, which are correlated with a higher ratio of beech, both live $(R 2=0.05, P=0.001)$ and dead $(R 2=0.27, P=$ 
0.001), whereas samples from natural forests with minimal human impact were associated with negative RDA2 values that are correlated with a higher presence of coniferous trees, both live (R2 = $0.09, p=0.001)$ and dead $(R 2=0.36, p=0.001)$. These results are also supported by the multiresponse permutation test, which confirmed differences in species composition between different decay stages $(R 2=0.10, P<0.001)$ and also between different sites $(R 2=0.15, P<0.001)$.

Tab. 3 Results of the SDR simplex approach, partitioning the relationship between a pair of sample units into three additive components summing up to 1 : similarity $(\mathrm{S})$ as measured by the Jaccard index, species replacement (R) and richness difference (D). Beta diversity (also called turnover, $T$ ) between pairs was expressed as $D+R$, and nestedness (Nest) as $S+D$. These functions were calculated between all site pairs (using cumulative species lists of the sites) and all log pairs. The difference of the statistics from randomness was tested by a Monte-Carlo simulation using 999 restricted permutations of the original matrix keeping the size and the presence fill of the matrix as well as the sampling unit species richness fixed.

\begin{tabular}{|c|c|c|c|c|c|}
\hline Site level & Mean value & $\begin{array}{l}\text { Confidence } \\
\text { interval lower } \\
(95 \%)\end{array}$ & $\begin{array}{l}\text { Confidence } \\
\text { interval upper } \\
(95 \%)\end{array}$ & Standard error & $\begin{array}{l}\text { Difference } \\
\text { from random }\end{array}$ \\
\hline $\mathrm{S}$ & 0.409 & 0.40838 & 0.40948 & $<0.001$ & Higher \\
\hline D & 0.116 & 0.11606 & 0.11616 & $<0.001$ & Higher \\
\hline $\mathrm{R}$ & 0.475 & 0.47437 & 0.47555 & $<0.001$ & Lower \\
\hline Betadiversity & 0.591 & 0.5905 & 0.59162 & $<0.001$ & Lower \\
\hline Nestedness & 0.525 & 0.52445 & 0.52563 & $<0.001$ & higher \\
\hline Log level & Mean value & $\begin{array}{l}\text { Confidence } \\
\text { interval lower } \\
(95 \%)\end{array}$ & $\begin{array}{l}\text { Confidence } \\
\text { interval upper } \\
(95 \%) \\
\end{array}$ & Standard error & $\begin{array}{l}\text { Difference } \\
\text { from random }\end{array}$ \\
\hline $\mathrm{s}$ & 0.064 & 0.06445 & 0.06449 & $<0.001$ & higher \\
\hline D & 0.249 & 0.24866 & 0.24867 & $<0.001$ & higher \\
\hline $\mathrm{R}$ & 0.687 & 0.68684 & 0.68689 & $<0.001$ & Lower \\
\hline Betadiversity & 0.936 & 0.93551 & 0.93555 & $<0.001$ & Lower \\
\hline Nestedness & 0.243 & 0.24304 & 0.24316 & $<0.001$ & higher \\
\hline
\end{tabular}

\section{Discussion}

\section{Different management history and current species richness and composition}

In this paper we present data from beech-dominated forest sites with old-growth structure in terms of the availability of coarse woody debris, the presence of large and senescent trees, and spontaneous development. All of them have remained unmanaged for at least 80 years and have never been clearcut in the past, but they have had different histories of human activities. Although all these sites currently provide sufficient good-quality substrates for wood inhabiting bryophytes, our results suggest that past human intervention negatively influenced the site and log level species richness as well as the species composition. In the past, selective felling in combination with full deadwood haulage and/or charcoal burning was focused on the largest trees - living or recently dead - which are the most important substrate for bryophytes (eg. Ódor et al. 2006; Hofmeister et al. 2015a). This effect was likely apparent long after management had ceased as a result of delay in species colonization. This is consistent with most studies dealing with the diversity of different groups of organisms bound to live trees and dead wood in forest ecosystems (e.g. Brunet et al. 2010; Nordén et al. 2014; Flensted et al. 2016). 
Once the continuity of the forest is disturbed, restoration of wood-inhabiting communities is longlasting process (Andersson and Hytteborn 1991, Ódor et al. 2006, Heilmann-Clausen et al. 2014). One of the main reasons is forest fragmentation, which is common in the European landscape (Kolb and Diekmann 2004; Fritz et al. 2008a; Flensted et al. 2016). In fragmented landscapes with small patches of well-preserved forests often very isolated from each other, recovery is limited by several factors such as dispersal abilities, permeability of the landscape or the availability of suitable microhabitats (Nordén and Appelqvist 2001; Pharo and Zartman 2007; Ódor et al. 2013). The smaller the area of unmanaged stands and the greater the distance to the nearest refuge, the less likely species are to survive (Hofmeister et al. 2015a).

One factor that complicates the interpretation of our results is the fact that in central Europe the intensity of management history is very often correlated with elevation. Forests in lowlands have been influenced by human activities for much longer and more intensively than more-inaccessible mountain forests (Kaplan et al. 2009; Chytrý 2012). The positive relationship of the species richness of bryophytes to the rising altitude has been described earlier (Bruun et al. 2006) and these two factors are so closely linked that it is difficult to separate their common influence. This needs to be considered when interpreting the results, however we hope that within one vegetation type this effect could be minor.

\section{The strong effect of decay stage}

Decay stage also had a significant effect on both species richness and species composition. The highest species richness was associated with DS 0 , i.e. living trees, and decreased with increasing decay stage. The initial high species richness resulted from the high proportion of epiphytic species in the community, which decreases rapidly during the decay process because of gradual bark loss. Late decay stages are represented mostly by generalists, since epixylic specialists prefer the logs of conifers because of more suitable substrate $\mathrm{pH}$ and water holding capacity (Táborská et al. 2015).

Considering the beta diversity between decay stages within sites, it was higher on logs (DS 1 and DS 2) than on trunks (DS 0), in contrast to species richness. The higher beta diversity on logs likely resulted from higher habitat diversity. Logs are more heterogeneous, consisting of a mosaic of microhabitats like bark, soft wood, rot holes or humus, while trunks are much more uniform and extreme in terms of microclimatic conditions (desiccation, direct sun shine, abrasion etc.), especially in the case of beech. Generally, beta diversity between trunks is mainly driven by different tree species (Mežaka et al. 2012; Ódor et al. 2013) and tree size (Fritz 2008b; Király et al. 2013), but in our case these factors were excluded by the sampling design.

We found that within-site beta diversity was lower than between-site beta diversity. The site effect was significant, but relatively small. In species composition, decay stage effect overwhelmed the differences between sites. On a larger (continental) scales, regional differences for wood inhabiting bryophyte communities are very strong and more important than local factors (Quian et al. 1998; Ódor et al. 2006; Heilmann-Clausen et al. 2014). Also, within a region the differences among sites are generally more important for species composition than within site factors like decay stage, driven mainly by climatic differences (Ódor and van Hees 2004). In our study we included data not only from lying logs (DS 1 and DS 2) but also from live trunks (DS 0). These two substrates have very different conditions (mainly water holding capacity, surface $\mathrm{pH}$ ) and there was also a large difference between our DS 0 and DS $1-2$ in terms of physical and chemical properties. This could explain why in our case decay stage had a stronger effect on species composition than the site. 


\section{Nestedness and beta diversity in old-growth forests with different management histories}

Based on the SDR analysis we found that wood-inhabiting bryophyte communities in our studied sites are nested. In other words, the species composition of species-poor plots is a subset of richer plots (Patterson and Atmar 1986). This was true both on the site and log levels. The beta diversity of wood-inhabiting bryophytes was lower than random both on the site and log levels. These results indicate that there is a significant proportion of shared species present both in species-rich and species-poor communities resulting in small differences in beta diversity; this is typical for organisms with good dispersal ability (Qian 2009). While the long-distance dispersal ability of bryophytes is still under discussion (Laaka-Lindberg et al. 2006; Barbe et al. 2016), on a local scale most bryophytes are considered to be good colonizers due to their microscopic wind-dispersed spores and the generally rich production of propagules (Frahm 2008). In addition to common species, we found a group of rare species that were arranged in a nested pattern (eg. Neckera pennata, Nowellia curvifolia, Pseudoamblystegium subtile, Zygodon dentatus). This group is represented by substrate specialists that tend to increase in number with rising habitat heterogeneity (Brunet et al. 2010) in space and time.

Based on our data we found that beta diversity and site level species richness are independent of each other. This is consistent with Hofmeister et al. (2015b), who published similar results for bryophytes in their study comparing forests with different current management intensity to nature reserves. Ujházyová et al. (2016) also confirmed that the species richness and beta diversity of beech forest vegetation can be driven by different environmental factors. Moreover, site- and log-level species richness were related to the intensity of management in the past while beta diversity was independent of it. The present lower species richness on sites with broken continuity could be explained by local extinctions caused by a lack of suitable microhabitats in the past. Beta diversity, on the other hand, reflects current local conditions and environmental heterogeneity of the studied substrate independently of the management history.

\section{Implications for nature conservation}

Our study confirms that forest conservation activities should be aimed at the protection of natural sites and improvements to their connectivity in fragmented landscapes. This is in line with the conclusion of the review of Nordén et al. (2014) that permanent reserves are still key conservation tool. Dispersal limitation in combination with random extinctions, and possibly also colonization delay, are the strongest factors threatening current wood-inhabiting bryophyte populations and complicating their re-establishment after disturbances (Fritz et al. 2008a). The isolation of natural and old-growth forests could be reduced by retention forestry management, which introduces the inclusion of oldgrowth attributes in managed forests (Lindenmayer et al. 2012, Fedrowitz et al. 2014). The presence of large senescent trees of different species and coarse woody debris of different volumes and decay stages is crucial for the survival of specialized species (Hofmeister et al. 2015a). However, nature conservation expectations should be realistic with respect to the management history of the site, since as our study demonstrates the quality of old-growth forests is strongly limited by past human impacts, at least within the time period we focused on. We also found that beta diversity indices are good for measuring environmental heterogeneity, but should not be used as indicators of the biodiversity value for bryophyte communities. 
2 In this study we analyzed wood-inhabiting bryophytes in seven beech-dominated old-growth 3 forests with different management intensities in the past. We confirmed an impoverishment in terms 4 of both species richness and composition on sites with previous human intervention. This is consistent 5 with studies describing the influence of forest continuity disruption on different groups of specialized 6 organisms. On the other hand, we found no relationship between management history and site- and 7 log-level beta diversity. Unlike simple species richness, indices of beta diversity give us information 8 about the current habitat heterogeneity and species niche preferences. The effect of decay stage on 9 species richness, composition and beta diversity was stronger than the effect of site. We included live 10 tree trunks, considered decay stage zero, and distinguished only two decay stages for dead logs. These classes differed significantly from each other from the point of view of their physical and chemical properties, leading to clear differences in all studied parameters. To preserve diverse wood-inhabiting bryophyte communities, protection of current old-growth forests and improvements in their mutual connectivity must be provided. 
2 Figures:

3 Fig. 1 Site-level (a) and log-level (b) species richness recorded on 243 logs at 7 old-growth beech4 dominated sites in the Czech Republic. Site name abbreviations are listed in Table 1. Each site was 5 associated to one of the three levels of human influence in the past according to Table 1 which are 6 indicated by different colors. Significant differences based on Tukey multiple comparisons are marked 7 by different letters.

8
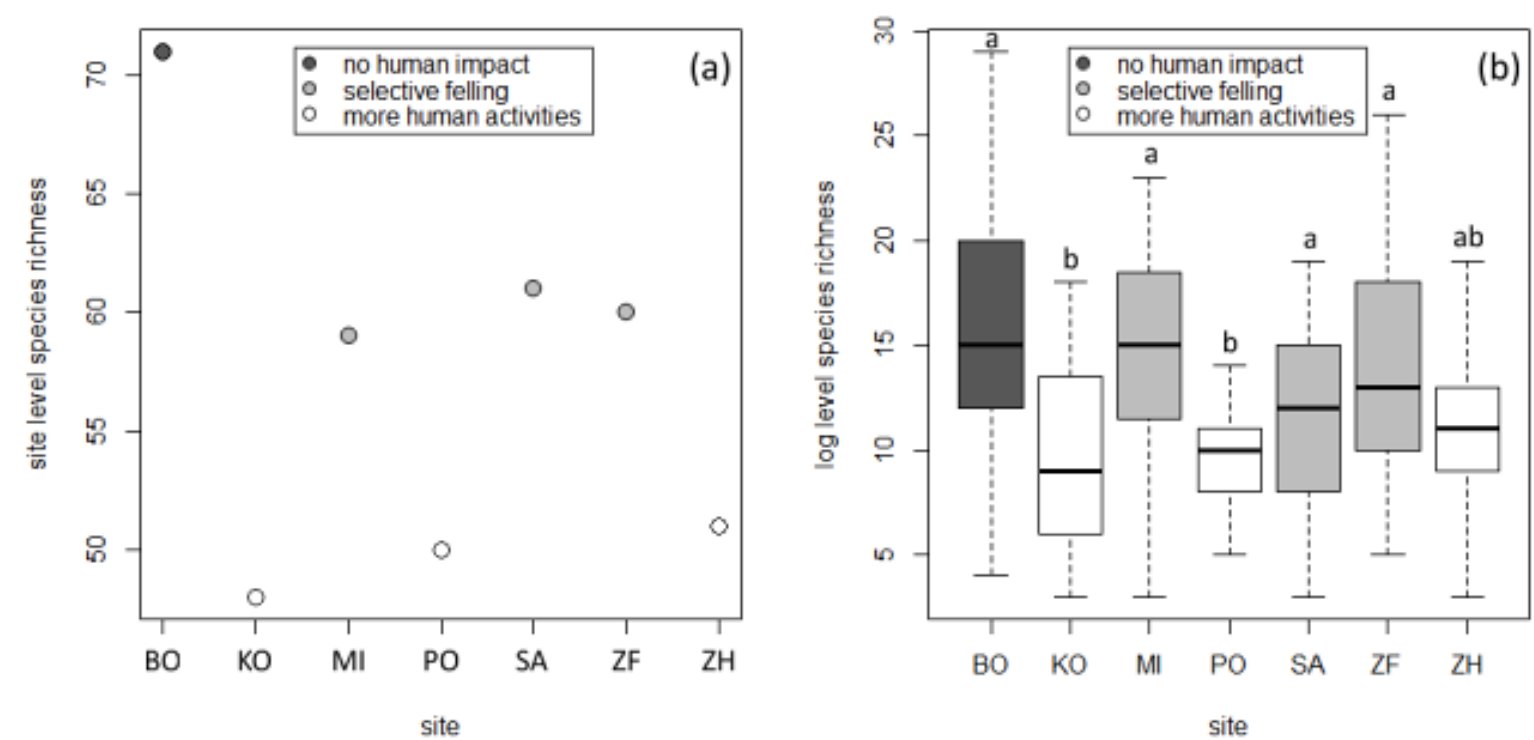

9 
2 Fig. 2 Decay stage level species richness recorded on 243 logs at 7 old-growth beech-dominated sites 3 in the Czech Republic. For a description of the used decay stages see the "Material and Methods". 4 Significant differences based on Tukey multiple comparisons are marked by different letters.

5

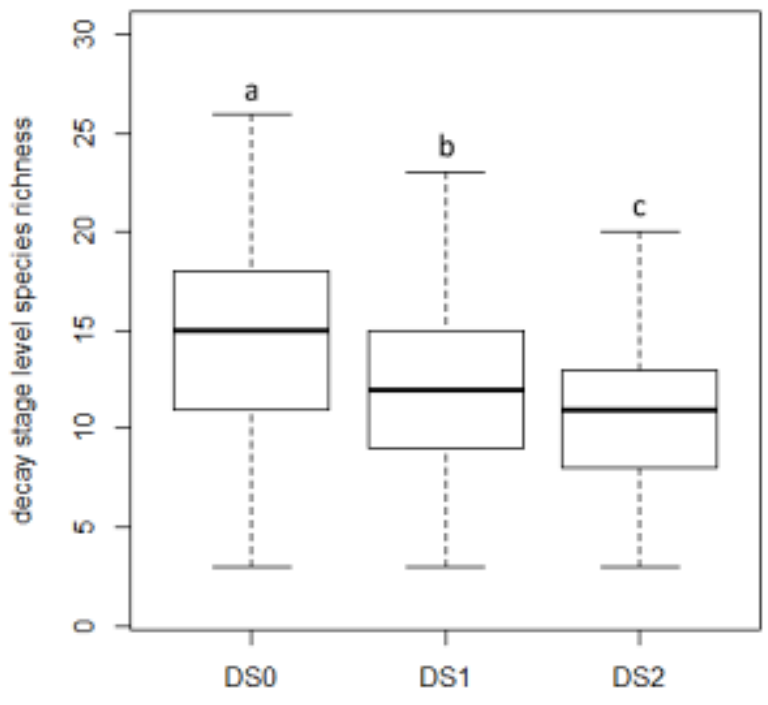

6 
2 Fig. 3 SDR simplex approach involves partitioning the relationship between a pair of sample units into 3 three additive components: $\mathrm{S}=$ similarity, $\mathrm{R}=$ species replacement, $\mathrm{D}=$ species richness difference. 4 The position of each data point within the ternary plot (the distance from each vertex and site) 5 characterizes the type of difference in community structure measured between each pair of sites. For 6 a more detailed explanation of this type of plotting see Podani and Schmera (2011) and Halme et al. 7 (2013).

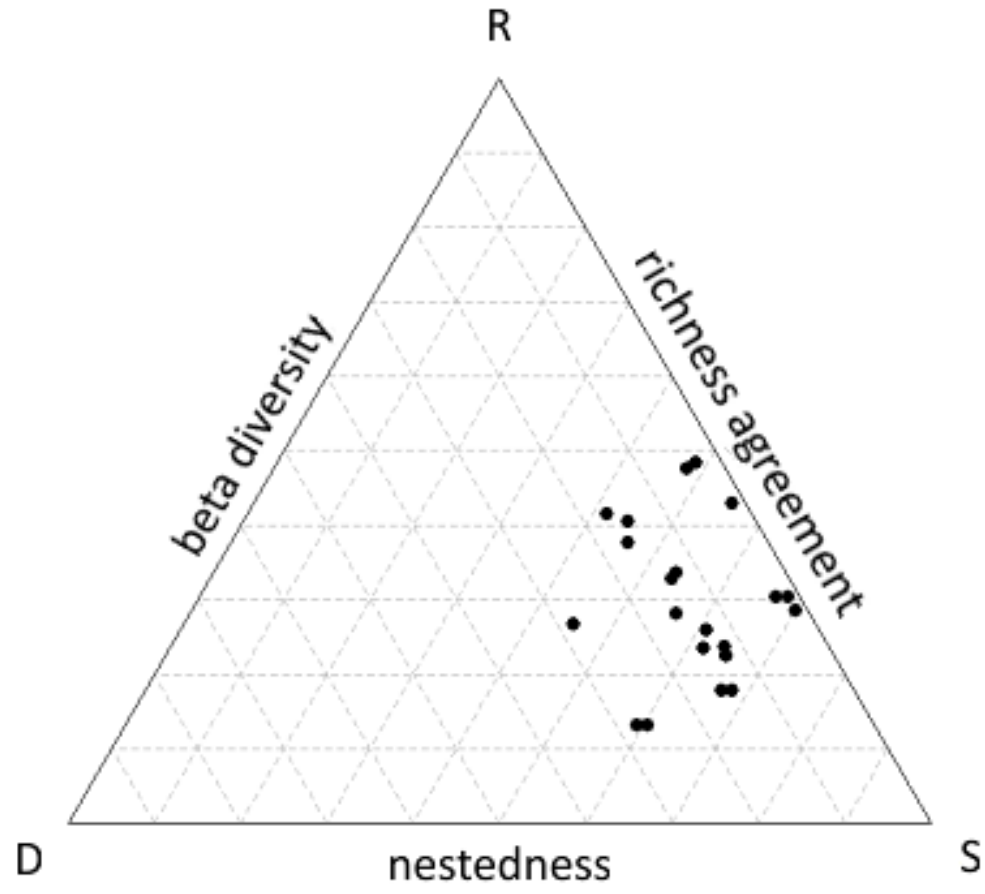

9 
2 Fig 4. Beta diversity between (B) and within (W) sites (a), and beta diversity between (B) and within 3 (W) decay stages within site (b). The differences of median values were significant $(p<0.001)$, based on 4 a Monte-Carlo simulation.

5

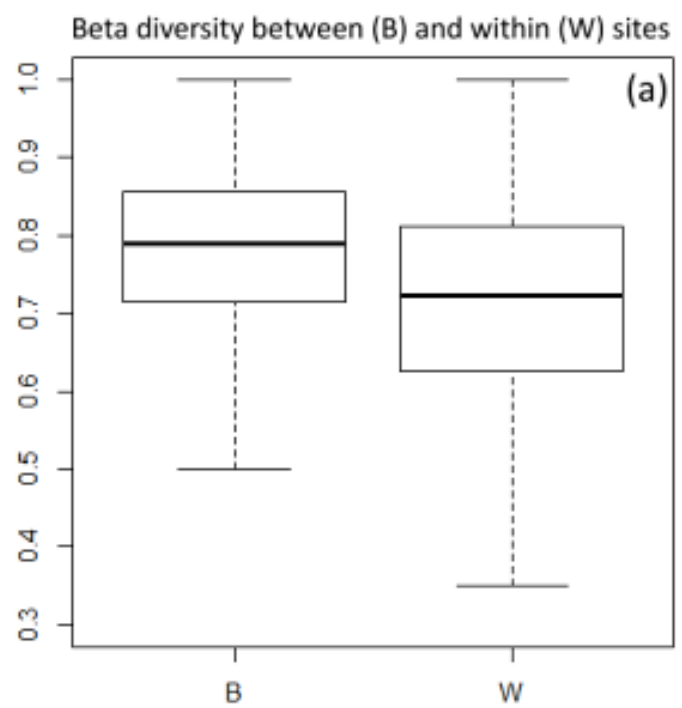

Beta diversity between (B) and within (W) decay stages within sites

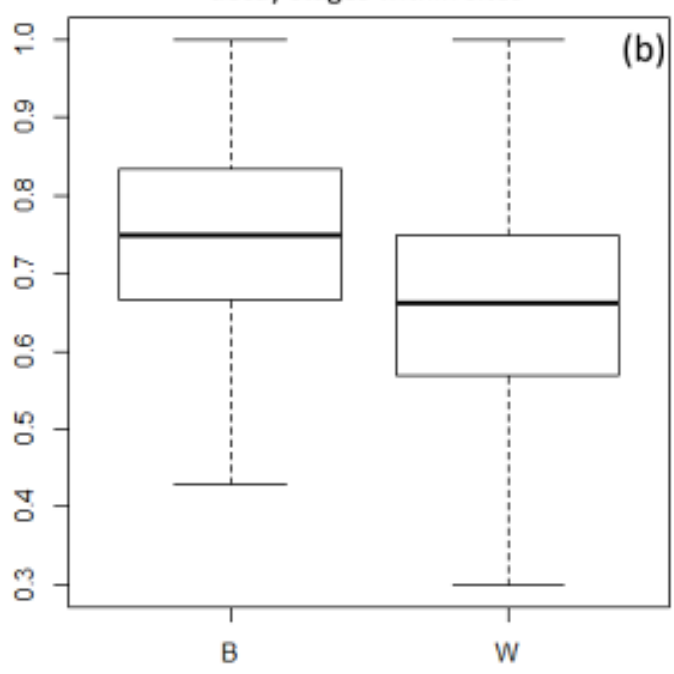


2 Fig. 5. Relationship between bryophyte species richness in the sites and average within-site beta 3 diversity $(F=0.4, p=0.56)$. Each site was associated to one of the three levels of human influence in 4 the past according to Table 1.

5

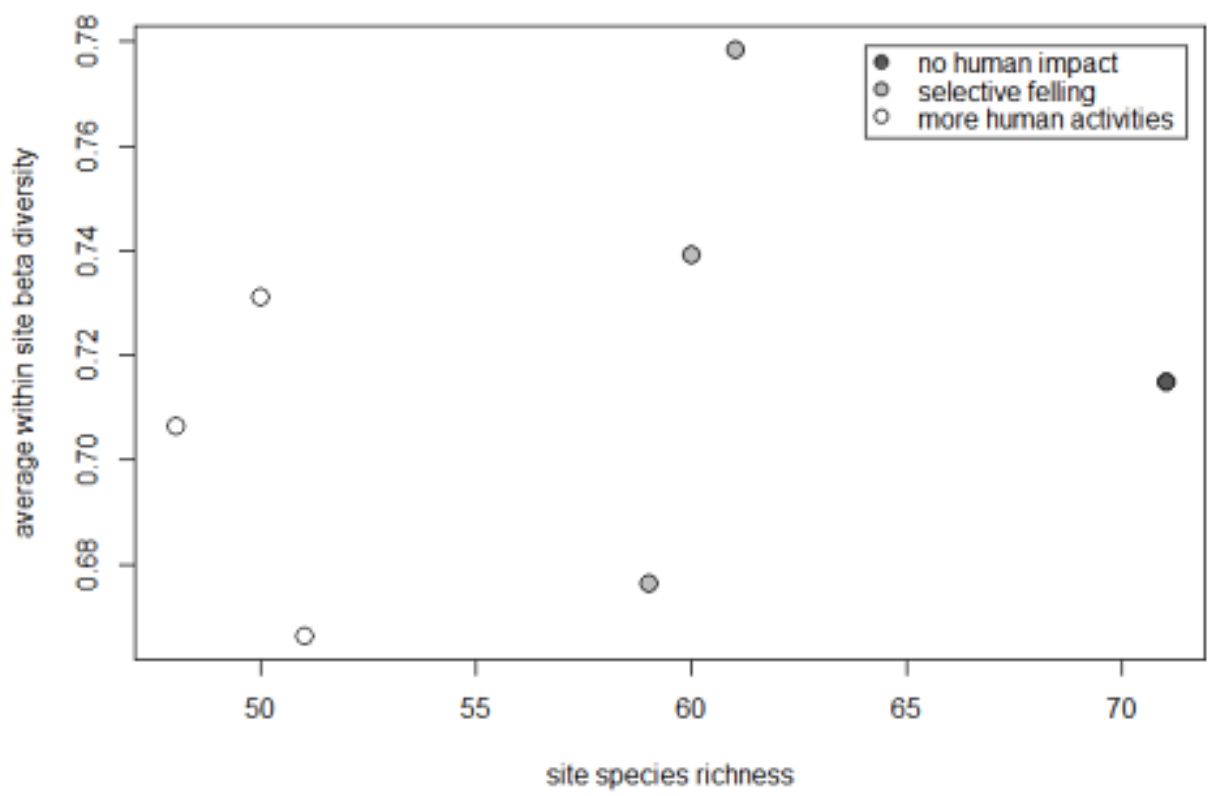

6

7 
2 Fig. 6. Boxplot of the beta diversity of sites $(F=51.7, p<0.001)$. Significant differences based on Tukey 3 multiple comparisons are marked by different letters. Site are colored based on their human influence 4 categories (Table 1), which were not related to beta diversity.

5

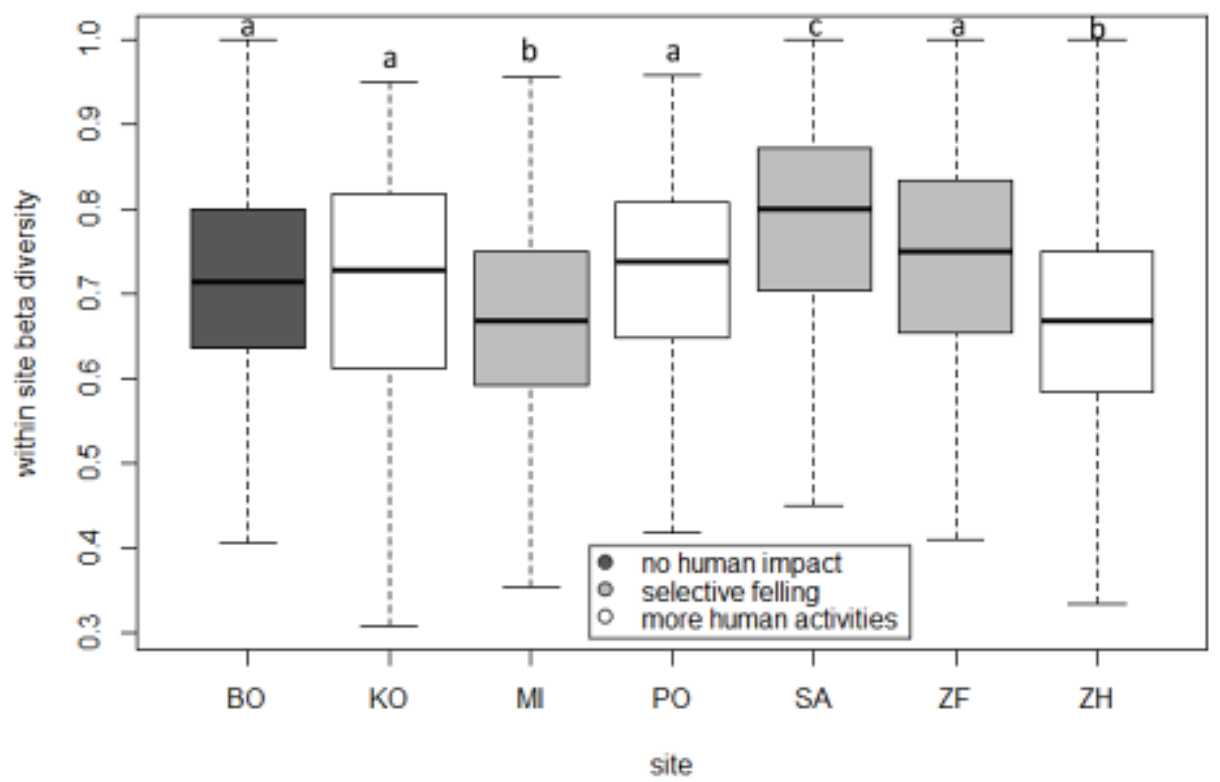

6

7

8 
1 Fig. 7. Boxplot of the beta diversity of decay stages ( $F=24.23, p<0.001$, permutation test). Beta diversity 2 values were calculated within sites and within decay stages.

3

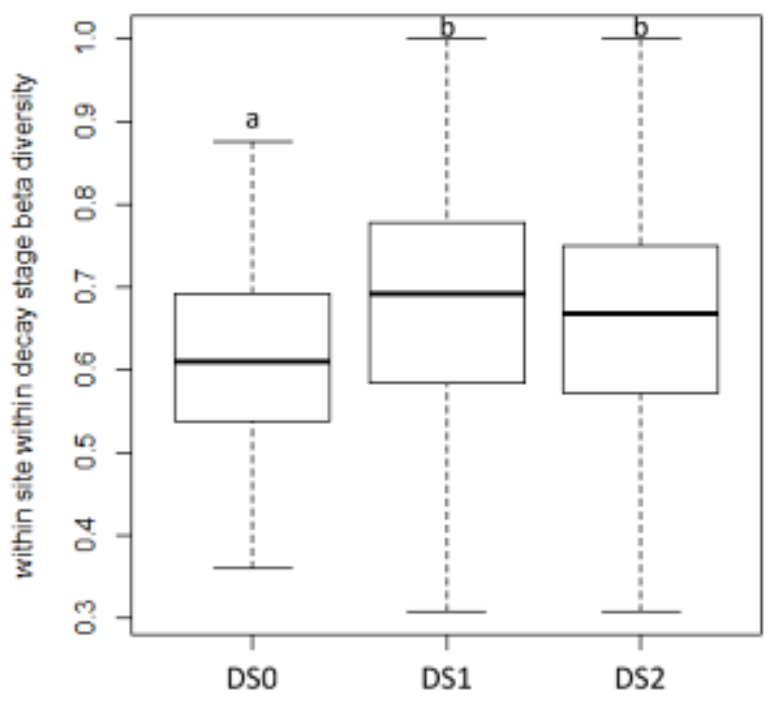


2 Fig. 8 RDA ordination of logs, marked by different human intervention categories of sites. The 3 explanatory factors are decay stages (red) and sites (green).

4

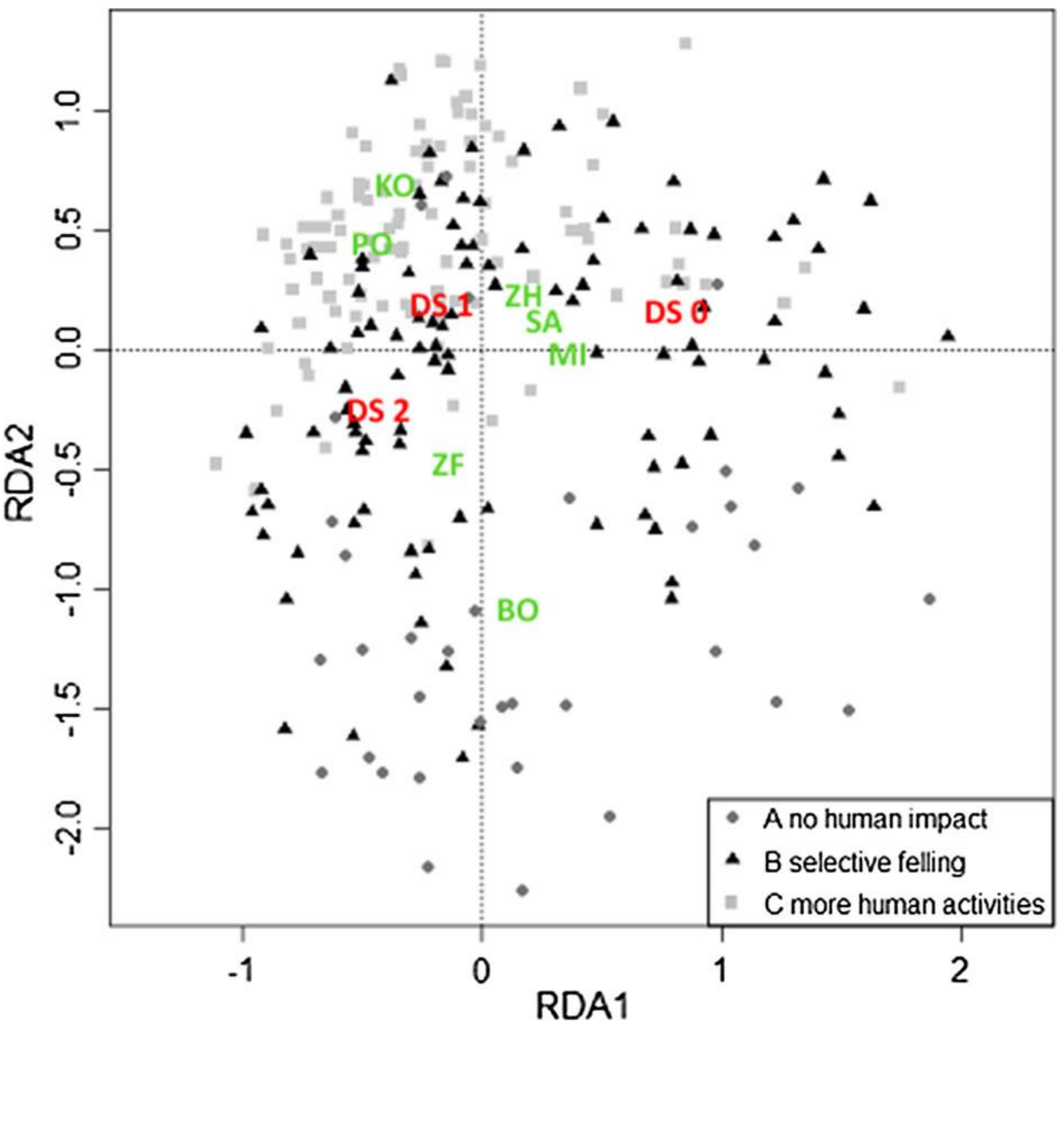


Anderson MJ (2001) A new method for non parametric multivariate analysis of variance. Austral Ecology 26:32-46. doi: 10.1111/j.1442-9993.2001.01070.pp.x

Anderson MJ, Crist TO, Chase JM, et al (2011) Navigating the multiple meanings of $B$ diversity: A roadmap for the practicing ecologist. Ecol Lett 14:19-28. doi: 10.1111/j.1461-0248.2010.01552.x

Andersson LI, Hytteborn H (1991) Bryophytes and decaying wood : a comparison between managed and natural forest. Holarctic Ecology 14:121-130.

Atmar W, Patterson BD (1993) The measure of order and disorder in the distribution of species in fragmented habitat. Oecologia 96:373-382.

Barbe M, Fenton NJ, Bergeron Y, Vesk P (2016) So close and yet so far away: long-distance dispersal events govern bryophyte metacommunity reassembly. J Ecol 104:1707-1719. doi: 10.1111/13652745.12637

Bauhus J, Puettmann K, Messier C (2009) Silviculture for old-growth attributes. For Ecol Manage 258:525-537. doi: 10.1016/j.foreco.2009.01.053

Berglund H, Jonsson BG (2003) Nested plant and fungal communities; the importance of area and habitat quality in maximizing species capture in boreal old-growth forests. Biol Conserv 112:319328. doi: 10.1016/S0006-3207(02)00329-4

Bohn U, Gollub G, Hettwer C, Neuhäuslová Z, Schlüter H, Weber H. (eds) (2003) Map of the natural vegetation of Europe. Bundesamt für Naturschutz, Bonn.

Borcard D, Gillet F et al. (2011) Numerical Ecology with R. Springer, New York.

Box EO, Fujiwara K (2005) Vegetation types and their broad-scale distribution. In: van der Maarel E (ed.) Vegetation ecology, Blackwell Publishing, Oxford, pp 106-128

Brunet J, Fritz Ö, Richnau G (2010) Biodiversity in European beech forests - a review with recommendations for sustainable forest management. Ecol Bull 53:77-94.

Bruun HH, Moen J, Virtanen R, et al (2006) Effects of altitude and topography on species richness of vascular plants, bryophytes and lichens in alpine communities. J Veg Sci 17:37-46. doi: 10.1111/j.1654-1103.2006.tb02421.x

Carvalho JC, Cardoso P, Borges PA V, et al (2013) Measuring fractions of beta diversity and their relationships to nestedness: A theoretical and empirical comparison of novel approaches. Oikos 122:825-834. doi: 10.1111/j.1600-0706.2012.20980.x

Chytrý M (2012) Vegetation of the Czech Republic: Diversity, ecology, history and dynamics. Preslia 84:427-504.

Crawley MJ (2007) The R book. John Wiley \& Sons Ltd, United Kingdom.

Ellis CJ (2012) Lichen epiphyte diversity: A species, community and trait-based review. Perspect Plant Ecol Evol Syst 14:131-152. doi: 10.1016/j.ppees.2011.10.001 
Fahrig L (2013) Rethinking patch size and isolation effects: The habitat amount hypothesis. J Biogeogr 40:1649-1663. doi: 10.1111/jbi.12130

Fedrowitz K, Koricheva J, Baker SC, et al (2014) Can retention forestry help conserve biodiversity? A meta-analysis. J Appl Ecol 51:1669-1679. doi: 10.1111/1365-2664.12289

Felton A, Lindbladh M, Brunet J, Fritz Ö (2010) Replacing coniferous monocultures with mixed-species production stands: An assessment of the potential benefits for forest biodiversity in northern Europe. For Ecol Manage 260:939-947. doi: 10.1016/j.foreco.2010.06.011

Flensted KK, Bruun HH, Ejrnaes R, et al (2016) Red-listed species and forest continuity - A multi-taxon approach to conservation in temperate forests. For Ecol Manage 378:144-159. doi: 10.1016/j.foreco.2016.07.029

Frahm JP (2008) Diversity, dispersal and biogeography of bryophytes (mosses). Biodivers Conserv 17:277-284. doi: 10.1007/s10531-007-9251-x

Friedel A, Oheimb G V., Dengler J, Härdtle W (2006) Species diversity and species composition of epiphytic bryophytes and lichens - A comparison of managed and unmanaged beech forests in NE Germany. Feddes Repert 117:172-185. doi: 10.1002/fedr.200511084

Fritz Ö, Gustafsson L, Larsson K (2008a) Does forest continuity matter in conservation? - A study of epiphytic lichens and bryophytes in beech forests of southern Sweden. Biol Conserv 141:655668. doi: 10.1016/j.biocon.2007.12.006

Fritz Ö, Niklasson M, Churski M (2008b) Tree age is a key factor for the conservation of epiphytic lichens and bryophytes in beech forests. Appl Veg Sci 12:93-106.

Gamborg C, Larsen JB (2003) "Back to nature"-a sustainable future for forestry? For Ecol Manage 179:559-571. doi: 10.1016/S0378-1127(02)00553-4

Hahn K, Fanta J (eds) (2001) Contemporary beech forest management in Europe. NAT-MAN Working Report 1.

Halme P, Ódor P, Christensen M, et al (2013) The effects of habitat degradation on metacommunity structure of wood-inhabiting fungi in European beech forests. Biol Conserv 168:24-30. doi: 10.1016/j.biocon.2013.08.034

Harmon ME, Franklin JF, Swanson FJ, et al (1986) Ecology of coarse woody debris in temperate ecosystems. Adv Ecol Res 15:133-302.

Heilmann-Clausen J (2001) A gradient analysis of communities of macrofungi and slime moulds on decaying beech logs. Mycol Res 105:575-596. doi: 10.1017/S0953756201003665

Heilmann-Clausen J, Aude E, van Dort K, et al (2014) Communities of wood-inhabiting bryophytes and fungi on dead beech logs in Europe - reflecting substrate quality or shaped by climate and forest conditions? J Biogeogr 2269-2282. doi: 10.1111/jbi.12388

Hofmeister J, Hošek J, Brabec M, et al (2015a) Value of old forest attributes related to cryptogam species richness in temperate forests: A quantitative assessment. Ecol Indic 57:497-504. doi: 10.1016/j.ecolind.2015.05.015 
Hofmeister J, Hošek J, Holá E, Novozámská E (2015b) Decline in bryophyte diversity in predominant types of central European managed forests. Biodivers Conserv 24:1391-1402. doi: 10.1007/s10531-015-0863-2

Hokkanen PJ, Kouki J, Komonen A (2009) Nestedness, SLOSS and conservation networks of boreal herbrich forests. Appl Veg Sci 12:295-303. doi: 10.1111/j.1654-109X.2009.01031.x

Hothorn T, Bretz F, Westfall P (2008) Simultaneous inference in general parametric models. Biometrical J 50:346-363. doi: 10.1002/bimj.200810425

Jonsson BG, Kruys N, Ranius T (2005) Ecology of Species Living on Dead Wood - Lessons for Dead Wood Management. Silva Fenn 39:289-309.

Kaplan JO, Krumhardt KM, Zimmermann N (2009) The prehistoric and preindustrial deforestation of Europe. Quat Sci Rev 28:3016-3034. doi: 10.1016/j.quascirev.2009.09.028

Király I, Nascimbene J, Tinya F, Ódor P (2013) Factors influencing epiphytic bryophyte and lichen species richness at different spatial scales in managed temperate forests. Biodivers Conserv 22:209-223. doi: 10.1007/s10531-012-0415-y

Kolb A, Diekmann M (2004) Effects of environment, habitat configuration and forest continuity on the distribution of forest plant species. J Veg Sci 15:199-208. doi: 10.1111/j.16541103.2004.tb02255.x

Král K, McMahon SM, Janík D, et al (2014a) Patch mosaic of developmental stages in central European natural forests along vegetation gradient. For Ecol Manage 330:17-28. doi: 10.1016/j.foreco.2014.06.034

Král K, Valtera M, Janík D, et al (2014b) Spatial variability of general stand characteristics in central European beech-dominated natural stands - Effects of scale. For Ecol Manage 328:353-364. doi: 10.1016/j.foreco.2014.05.046

Kučera J, Váňa J, Hradílek Z (2012) Bryophyte flora of the Czech Republic: Updated checklist and red list and a brief analysis. Preslia 84:813-850.

Laaka-Lindberg S, Korpelainen H, Pohjamo M (2006) Spatial distribution of epixylic hepatics in relation to substrate in a boreal old-growth forest. J Hattori Bot Lab 100:311-323.

Larsen JB (1995) Ecological stability of forests and sustainable silviculture. For Ecol Manage 73:85-96. doi: 10.1016/0378-1127(94)03501-M

Leuschner C, Meier IC, Hertel D (2006) On the niche breadth of Fagus sylvatica: soil nutrient status in 50 Central European beech stands on a board range of bedrock types. Ann For Sci 63:355-368.

Lindenmayer DB, Franklin JF, Lõhmus A, et al (2012) A major shift to the retention approach for forestry can help resolve some global forest sustainability issues. Conserv Lett 5:421-431. doi: 10.1111/j.1755-263X.2012.00257.x

Löbel S, Snäll T, Rydin H (2006) Metapopulation processes in epiphytes inferred from patterns of regional distribution and local abundance in fragmented forest landscapes. J Ecol 94:856-868. doi: 10.1111/j.1365-2745.2006.01114.x 
Madžule L, Brūmelis G, Tjarve D (2011) Structures determining bryophyte species richness in a managed forest landscape in boreo-nemoral Europe. Biodivers Conserv 21:437-450. doi: 10.1007/s10531-011-0192-z

Mežaka A, Brūmelis G, Piterāns A (2012) Tree and stand-scale factors affecting richness and composition of epiphytic bryophytes and lichens in deciduous woodland key habitats. Biodivers Conserv 21:3221-3241. doi: 10.1007/s10531-012-0361-8

Moning C, Müller J (2009) Critical forest age thresholds for the diversity of lichens, molluscs and birds in beech (Fagus sylvatica L.) dominated forests. Ecol Indic 9:922-932. doi: 10.1016/j.ecolind.2008.11.002

Müller J, Hothorn T, Pretzsch H (2007) Long-term effects of logging intensity on structures, birds, saproxylic beetles and wood-inhabiting fungi in stands of European beech Fagus sylvatica L. For Ecol Manage 242:297-305. doi: 10.1016/j.foreco.2007.01.046

Näslund M (1936) Skogsförsöksanstaltens gallringsförsök i tallskog. Meddelanden från Statens Skogsförsöksanstalt. 29, pp 169. (in Swedish with German summary)

Nordén B, Appelqvist T (2001) Conceptual problems of ecological continuity and its bioindicators. Biodivers Conserv 10:779-791. doi: 10.1023/A:1016675103935

Nordén B, Dahlberg A, Brandrud TE, et al (2014) Effects of ecological continuity on species richness and composition in forests and woodlands: A review. Ecoscience 21:34-45. doi: 10.2980/21-1-3667

Ódor P, Heilmann-Clausen J, Christensen M, et al (2006) Diversity of dead wood inhabiting fungi and bryophytes in semi-natural beech forests in Europe. Biol Conserv 131:58-71.

Ódor P, Király I, Tinya F, et al (2013) Patterns and drivers of species composition of epiphytic bryophytes and lichens in managed temperate forests. For Ecol Manage 306:256-265. doi: 10.1016/j.foreco.2013.07.001

Ódor P, Standovár T (2001) Richness of bryophyte vegetation in near-natural and managed beech stands: the effects of management-induced differences in dead wood. Ecol Bull 49:219-229.

Ódor P, van Hees AFM (2004) Preferences of dead wood inhabiting bryophytes for decay stage, log size and habitat types in Hungarian beech forests. J Bryol 26:79-95.

Oksanen J, Blanchet FG, Friendly M, Kindt R, Legendre P, McGlinn D, Minchin PR, O'Hara RB, Simpson GL, Solymos P, Stevens MHH, Szoecs E, Wagner H (2016) vegan: Community Ecology Package. R package version 2.4-1. https://CRAN.R-project.org/package=vegan. Accessed 28 November 2016

Patterson BD, Atmar W (1986) Nested subsets and the structure of insular mammalian faunas and archipelagos. Biol J Linn Soc 28:65-82. doi: 10.1111/j.1095-8312.1986.tb01749.x

Peters R (1997) Beech Forests. Kluwer Academic Publishers, Dordrecht, Netherlands.

Pharo EJ, Zartman CE (2007) Bryophytes in a changing landscape: The hierarchical effects of habitat fragmentation on ecological and evolutionary processes. Biol Conserv 135:315-325. doi: 10.1016/j.biocon.2006.10.016 
Pícha J (2010) Historický vývoj dřevinné skladby Žofínského pralesa. Bachelor's thesis, Mendel University in Brno. (in Czech)

Pícha J (2012) Expanze buku v NPR Žofínský prales. Master's thesis. Mendel University in Brno. (in Czech)

Podani J, Schmera D (2011) A new conceptual and methodological framework for exploring and explaining pattern in presence - absence data. Oikos 120:1625-1638. doi: 10.1111/j.16000706.2011.19451.x

Průša E (1985) Státní prírodní rezervace Kohoutov, její ekologie a struktura. Lesnictví 31:989-1016. (in Czech)

Qian H (2009) Beta diversity in relation to dispersal ability for vascular plants in North America. Glob Ecol Biogeogr 18:327-332. doi: 10.1111/j.1466-8238.2009.00450.x

Qian H, Klinka K, Kayahara G (1998) Longitudinal patterns of plant diversity in the North American boreal forest. Plant Ecol 138:161-178. doi: 10.1023/A:1009756318848

R Core Team (2013): R: A language and environment for statistical computing. R Foundation for Statistical Computing, Vienna, Austria. http://www.R-project.org. Accessed 28 November 2016

Rambo TR, Muir PS (1998) Bryophyte species associations with coarse woody debris and stand ages in Oregon. Bryologist 101:366-376.

Samuelsson J, Gustafsson L, Ingelog T (1994): Dying and dead trees: a review of their importance for biodiversity. Swedish Threatened Species Unit, Uppsala.

Similä M, Kouki J, Martikainen P (2003) Saproxylic beetles in managed and seminatural Scots pine forests: quality of dead wood matters. For Ecol Manage 174:365-381. doi: 10.1016/S03781127(02)00061-0

Snäll T, Hagström A, Rudolphi J, Rydin H (2004) Distribution pattern of the epiphyte Neckera pennata on three spatial scales - Importance of past landscape structure, connectivity and local conditions. Ecography (Cop) 27:757-766. doi: 10.1111/j.0906-7590.2004.04026.x

Standovár T, Kenderes K (2003) A review on natural stand dynamics in beechwoods of East Central Europe. Appl Ecol Environ Res 1:19-46.

Táborská M, Přívětivý T, Vrška T, Ódor P (2015) Bryophytes associated with two tree species and different stages of decay in a natural fir-beech mixed forest in the Czech Republic. Preslia 87:387401.

Ujházyová M, Ujházy K, Chytrý M, et al (2016) Diversity of beech forest vegetation in the Eastern Alps, Bohemian Massif and the Western Carpathians. Preslia 88:435-457.

Vrška T (1998) Prales Salajka po 20 letech (1974-1994). Lesnictví 44:153-181. (in Czech)

Vrška T, Hort L, Odehnalová P, Adam D, Horal D (2000). Prales Mionší - historický vývoj a současný stav. Journal of Forest Science 46:411-424. (in Czech with English abstract) 
Vrška T, Hort L, Adam D, Odehnalová P, Horal D (2002) Dynamika vývoje pralesovitých rezervací v ČR I - Českomoravská vrchovina (Polom, Žákova hora) / Developmental dynamics of virgin forest reserves in the Czech Republic I - The Českomoravská vrchovina Upland (Polom, Žákova hora Mt.). Academia, Praha. (in Czech and English)

Vrška T, Šamonil P, Unar P, Hort L, Adam D, Král K, Janík D (2012) Dynamika vývoje pralesovitých rezervací v ČR III - Šumava a Český les (Diana, Stožec, Boubínský prales, Milešický prales) / Developmental dynamics of virgin forest reserves in the Czech Republic III - Šumava Mts. and Český les Mts. (Diana, Stožec, Boubín virgin forest, Milešice virgin forest). Academia, Praha. (in Czech and English)

Zar JH (1999) Biostatistical analysis. Prentice Hall, New Jersey.

Zerbe S (2002) Restoration of natural broad-leaved woodland in Central Europe on sites with coniferous forest plantations. For Ecol Manage 167:27-42. doi: 10.1016/S0378-1127(01)006867 
Appendix 1.

2

3 \#Analysis for SDR simplex (Podani and Schmera 2006)

4 \#Made by Attila Lengyel, 6/Jan/2017., version 2.2.

$\# A, B$ and C components are calculated first for each pair of sites ABCmat<-function(comm) \{ \#comm is the communitry matrix comm $[$ comm $>0]<-1$ 


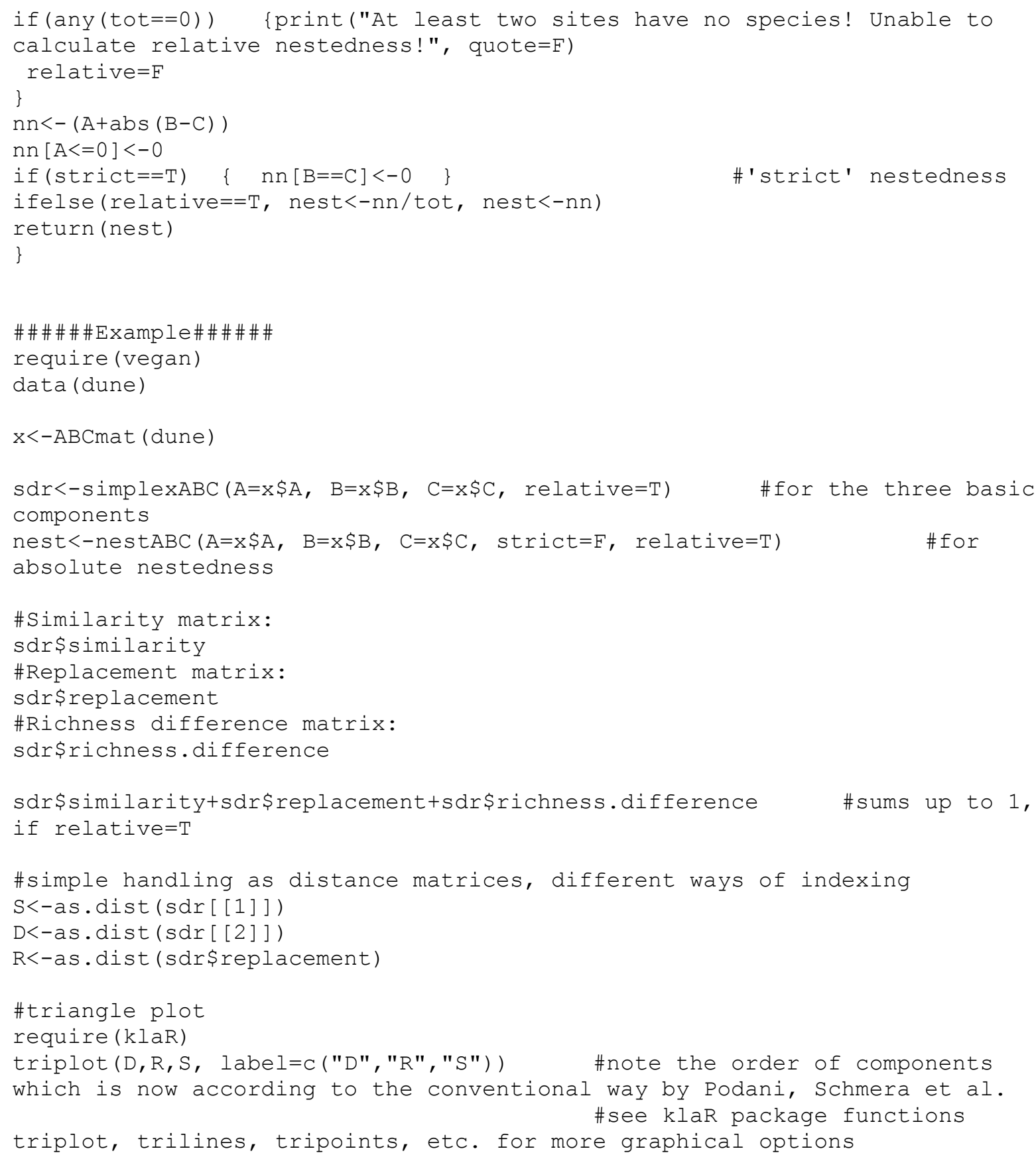

